Landslides (2020) 17:1743-1744 DOI 10.1007/s10346-020-01467-7 Received: 21 June 2020 Accepted: 22 June 2020 Published online: 15 July 2020 (c) Springer-Verlag GmbH Germany part of Springer Nature 2020

\section{Kyoji Sassa \\ Launching Session of the Kyoto Landslide Commitment 2020}

CL originally planned to organize the Fifth World Landslide Forum (WLF5) and launch the Kyoto Landslide Commitment 2020 (KLC2020) on 2-6 November 2020; however, due to the COVID-19 pandemic, the Organizing Committee of WLF5 decided to postpone the WLF5 for 1 year to 2-6 November 2021 at the same venue (Kyoto International Conference Center). Meanwhile, two thematic issues of Landslides titled "Sendai Landslide Partnerships 20152025" and six volumes of full color books titled "Understanding and Reducing Landslide Disaster Risk," which are the inaugural volumes of new ICL book series "ICL contribution to landslide disaster risk reduction (ISSN 2662-1894 (print version) and ISSN2662-1908 (electronic version)), will be published in October or November 2020, as initially scheduled. The KLC2020 will also be launched as initially scheduled on 5 November 2020 (World Tsunami Awareness Day) at the launching session of the Kyoto Landslide Commitment 2020 during the 2020 ICL-IPL online Conference on 2-6 November 2020. The plan and preparation of the launching session of the KLC2O20 are reported below.

\section{Launching Session of KLC2020}

Date: 5 November (Thursday) 2020 (online virtual meeting)

Time: 23 :00-01:00 PST (4 to 5 Nov.), 8:00-10:00 CET, 16:00-18:00 JST (120 min)

Participants: Representatives of KLC2020 signatories Objectives:

(1) To identify and recognize all participating organizations in the Commitment as KLC2020 partners.

All signatories of $\mathrm{KLC} 2 \mathrm{O} 2 \mathrm{O}$ including the first group of signatories in September 2019 will meet for the first time. This online virtual meeting will constitute the base of joint activities to be undertaken after launch.

(2) To organize the panel discussion to launch and develop the Kyoto 2020 Commitment for global promotion of Understanding and Reducing Landslide Disaster Risk (KLC2020) and to establish the KLC2O20 Secretariat.

(3) To adopt the Formal Declaration of the Launching of $\mathrm{KLC} 2 \mathrm{O} 2 \mathrm{O}$ and the Establishment of KLC2O2O Secretariat by all participating signatories.

\section{Program:}

1. Introductory session: 8:00-8:30 AM in CET Identification and recognition of each participating signatory as a KLC2020 partner

Each signatory organization is requested to submit an introduction (1,500-3,000 characters) of the organization, the activities and possible contribution to KLC2020 by 5 September 2020 to the ICL secretariat <secretariat@iclhq.org>. This introduction is combined into one file and distributed to all participants representing signatories of KLC 2020 before the Session. During this introductory session, each participant will therefore have the opportunity to recognize fellow partners. The introduction of KLC 2020 partners will be published in a series of issues of Journal Landslides in 2021. Group photo

A group photo will be taken as a screen shot of the online session system.

Each participant will be requested to send his/her good quality photo to the secretariat. The secretariat will publish the photo, name, affiliation, country of all participating representatives of signatories in an article to report the launching session of KLC2020 in the January issue of the Journal Landslides in 2021.

2. High-level panel discussion session to launch KLC2020: 8:309:50 AM in CET

Greeting messages: Signatories from ICL supporting organizations

(UN organizations, global stakeholders, governments, academia)

Panel discussion by panelists representing KLC2020 signatories Keynote Speech: Outline of KLC2020, Landslide Research Frontier (Landslide-induced tsunami)

Remarks from panelists: The initial activities of KLC2O2O and the strategy for the further development of KLC2020 to WLF5 in 2021 and later.

3. Formal declaration of the launching of KLC2O20 and the establishment of KLC2020 secretariat, and Closure: 9:5010:00 AM in CET

Schedule of preparation

\begin{tabular}{|c|c|c|}
\hline Date & Time & Activities \\
\hline $\begin{array}{l}5 \text { September } \\
2020 \text { (Saturday) }\end{array}$ & $\begin{array}{l}\text { By } 5 \text { Sept. } 2020 \text {, } \\
\text { participants are } \\
\text { requested to complete } \\
\text { two activities (as } \\
\text { indicated in right } \\
\text { column) }\end{array}$ & $\begin{array}{l}\text { Registration of KLC2020 } \\
\text { signatories to participate } \\
\text { in the launching session } \\
\text { Submission of introduction } \\
\text { of KLC2020 signatories } \\
\text { ( } 1500-3000 \text { characters) } \\
\text { and photo of participants }\end{array}$ \\
\hline $\begin{array}{l}3 \text { October } 2020 \\
\text { (Saturday) }\end{array}$ & $\begin{array}{l}\text { 23:00 (2 Nov.)-1:00 PST } \\
\text { 8:00-10:00 CET } \\
\text { 16:00-18:00 JST }\end{array}$ & $\begin{array}{l}\text { Rehearsal of the } \\
\text { launching session of } \\
\text { KLC } 2020 \text { by all available } \\
\text { signatories }\end{array}$ \\
\hline $\begin{array}{l}4 \text { November } \\
2020 \\
\text { (Wednesday) }\end{array}$ & $\begin{array}{l}\text { 22:00 (3 Nov.)-1:00 PST } \\
\text { 7:00-10:00 CET } \\
\text { 15:00-18:00 JST }\end{array}$ & $\begin{array}{l}\text { Planning WLF5 programme } \\
\text { and other KLC2020 activities } \\
\text { after its launching on } 5 \\
\text { November } 2020\end{array}$ \\
\hline $\begin{array}{l}5 \text { November } \\
2020 \\
\text { (Thursday) }\end{array}$ & $\begin{array}{l}\text { 23:00 (4 Nov.)-1:00 PST } \\
\text { 8:00-10:00 CET } \\
\text { 16:00-18:00 JST }\end{array}$ & $\begin{array}{l}\text { Launching session of } \\
\text { KLC2020 }\end{array}$ \\
\hline
\end{tabular}

Landslides $17 \cdot(2020)$ 
Landslides: Journal of the International Consortium on Landslides has published a series of Prefaces and Forewords on Journal, $\mathrm{WLF}_{5}$ and Kyoto Commitment to promote the $\mathrm{WLF}_{5}$ and Kyoto Commitment in 2018-2020.

The Journal Landslides developed from a bi-monthly journal to a monthly journal from January 2018 (Sassa 2018). Thereafter, the journal is able to take a role of newsletter for the international activities of ICL. Quick information pages of WLF5 and Kyoto Commitment were created within the backmatter of Landslides from Vol. 15, No. 7 in 2018. Information in the backmatter can be contributed some weeks before online publication of each issue.

At the high-level panel discussion in the Fourth World Landslide Forum in Ljubljana, Slovenia in 2017, the basic concept of Kyoto Landslide Commitment 2020 was proposed and accepted. In order to provide a common platform to the Kyoto Landslide Commitment, a new category of News/Kyoto Commitment was created in 2018 (Sassa 2019b). Thereafter, the progress of WLF5 (Sassa 2019a) and Kyoto Commitment (Sassa 2019c) and news and reports of activities from KLC2020 promoting partners were published. Within those, forewords from the following ICL supporting organizations were published in 2018-2020: the United Nations Office for Disaster Risk Reduction (Mizutori 2020), the United Nations Educational, Scientific and Culture Organization (Nair-Bedouelle 2020), the United Nations University (Oki 2019), the Food and Agriculture Organization of the United Nations (Mitsugi 2018), and Kyoto University (Yamagiwa 2018). The Agency for Meteorology Climatology and Geophysics (BMKG) of the Government of Indonesia expressed its strong support to the planned Kyoto Landslide Commitment 2020 in her foreword (Karnawati 2018).

\section{Call for KLC2020 signatories}

Sixty-seven United Nations, International and national organizations have joined the KLC2O2O as of 23 June 2020. The ICL secretariat in Kyoto, Japan serves as the secretariat of the Kyoto Landslide Commitment 2020. The ICL calls for further KLC2O2O signatories to voluntarily commit to the global promotion of understanding and reducing landslide disaster risk.

Potential partners of the KLC2O20 are the followings:

1. ICL member organizations (full members, associate members, and supporters)

2. ICL supporting organizations from the UN system, international or national organizations, and programmes

3. Government ministries and offices in countries having more than 2 ICL ongoing members

4. International associations/societies which contribute to the organization of WLF5 in 2021 and WLF6 in 2023

5. Other organizations having some aspects of activities related to understanding and reducing landslide disaster risk as their intrinsic missions>

Notes:

- KLC 2020 is a commitment to the Sendai Landslide Partnerships 2015-2025, the Sendai Framework for Disaster Risk
Reduction 2015-2030, the 2030 Agenda Sustainable Development Goals, the New Urban Agenda, and the Paris Climate Agreement. Its follow-up does not require any additional duties or responsibilities from the partners other than their own intrinsic works/mandates. All KLC2020 partners are those organizations who already have division(s)/entity(ies) whose intrinsic missions are related to understand and reduce landslide disaster risk. Accordingly, their success in carrying out their missions is in itself the successful commitment to KLC2O2O.

- KLC 2020 is planned to continue further to 2030, and beyond. KLC 2020 will be examined at each World Landslide Forum every 3 years. Priority actions will be updated, so will Partners of KLC 2020, some partners will be added, and some partners may leave due to various reasons such as changes of society, landslide scope, or partners themselves. As such, KLC2O20 is a living and growing partnership.

Potential partners are invited to inform their willingness to ICL secretariat <secretariat@iclhq.org> with subject "KLC2020 registration". ICL will then send the invitation letter to sign the $\mathrm{KLC} 2 \mathrm{O} 2 \mathrm{O}$ and attend the online launching session of KLC2O2O on 5 November 2020. All new participating signatories are also requested to submit the introduction of the organization (1500-3000 characters) and a photo of the participant by 5 September 2020 to the secretariat.

\section{References}

Karnawati D (2018) Foreword by Dwikorita Karnawati for the Journal of the International Consortium on Landslides. Landslides 15(8):1457-1458

Mitsugi H (2018) Foreword by Hiroto Mitsugi for the Journal of the International Consortium on Landslides. Landslides 15(12):2,323-2,324

Mizutori M (2020) Foreword for the Journal of the International Consortium on Landslides. Landslides 17(4):753

Nair-Bedouelle S (2020) Foreword by Shamila Nair-Bedouelle for the Journal of the International Consortium on Landslides. Landslides 17(1):1

Oki T (2019) Foreword by Prof. Taikan Oki of the United Nations University (UNU) for the Journal of the International Consortium on Landslides. Landslides 16(12):2,299-2,300

Sassa K (2018) Monthly publication of Landslides: Journal of International Consortium on Landslides (ICL). Landslides 15(1):1-3

Sassa K (2019a) The Fifth World Landslide Forum and the final draft of the Kyoto 2020 Commitment. Landslides 16(2):201-211

Sassa K (2019b) Journal Landslides, the International Consortium on Landslides, and the Kyoto Landslide Commitment 2020. Landslides 16(9):1623-1628

Sassa K (2019c) The Kyoto Landslide Commitment 2020: first signatories. Landslides 16(11):2053-2057

Yamagiwa J (2018) Foreword by Juichi Yamagiwa for the jJournal of the International Consortium on Landslides. Landslides 15(3):387-388

K. Sassa (四)

International Consortium on Landslides (ICL),

Kyoto, Japan

Email: secretariat@iclhq.org 